Proc. Indian Acad. Sci. (Earth Planet. Sci.), Vol. 99, No. 1, March 1990, pp. 133-140.

(C) Printed in India.

\title{
Problems of pressure estimation in high temperature experiments using solid media apparatus; pressure calibration with reference to breakdown of albite and quartz-coesite transformation (Part II)
}

\author{
ROBERT A ISHBULATOV and ALEXANDER V KOSYAKOV \\ Institute of Experimental Mineralogy, USSR Academy of Sciences, 142432 Chernogolovka \\ Moscow District, USSR

\begin{abstract}
The high albite $(\mathrm{Ab}) \rightleftharpoons$ jadeite $(\mathrm{Jd})+$ quartz(Q) reaction (1) and the quartz $(\mathrm{Q}) \rightleftarrows$ coesite (Cs) transformation (2) have been determined within the temperature range of $1000-1100^{\circ} \mathrm{C}$ and $1000-1400^{\circ} \mathrm{C}$ respectively under variable pressures using an anvilwith-hole apparatus. The equilibrium curves for the two reactions as a function of $P$ and $T$ are as follows:

$P=-1.33+0.0296 T$ (reaction 1); $P=18.949+0.0111 T$ (reaction 2). These two lines intersect at $31.1 \pm 0.5 \mathrm{~kb}$ and $1096^{\circ} \mathrm{C}$. The possibility of using an anvil-with-hole apparatus for conducting current investigations is discussed in this paper.
\end{abstract}

Keywords. Pressure calibration; albite; quartz-coesite.

\section{Introduction}

Careful pressure-temperature calibration is very important in the study of phase equilibria as it is the only way to correlate data obtained from different laboratories with the help of solid media apparatus. The equilibria $A b=J d+Q$ and $Q=C s$ are often used for this purpose. The precise absolute values of $P-T$ parameters of these equilibria are unknown, though there have been multiple attempts to determine them.

Hays and Bell (1973) studied the analbite breakdown reaction in a gas apparatus at $600^{\circ} \mathrm{C}$. It was found that at $16.2 \pm 0.3 \mathrm{~kb}$ the reaction proceeds with albite growth but at $16.7 \pm 0.3 \mathrm{~kb}$ this reaction is reversed, i.e. the equilibrium pressure is 16.45 $\pm 0.55 \mathrm{~kb}$. Determination of equilibrium pressure in the piston cylinder apparatus at $600^{\circ} \mathrm{C}$ (which was carried out by workers from six different laboratories) has also revealed considerable deviations from this point $(15.7-16.8 \mathrm{~kb})$ for runs at relatively low pressures. Incidentally, the data on the salt cell $(\mathrm{NaCl} ; 16.2 \pm 0.5 \mathrm{~kb}$; Johannes et al 1971) could be compared with precise hydrostatic determination. The higher accuracy of pressure measurements at a given equilibrium at $600^{\circ} \mathrm{C}$ using salt cells (as compared to talc and pyrophyllite ones) has been proposed experimentally (Johannes 1978).

Holland (1980) studied this reaction within the temperature range of $600-1200^{\circ} \mathrm{C}$ using the salt cell and proposed the following equation for the equilibrium line:

$$
\begin{aligned}
P= & 0.35+0.0265 \pm 0.5(\mathrm{~kb}) \\
& \left(16.25 \pm 0.25 \mathrm{~kb} \text { at } 600^{\circ} \mathrm{C}\right)
\end{aligned}
$$

Mirwald and Massone (1980) also used the salt cell for pressure equilibrium 
measurements at $1090^{\circ} \mathrm{C}$ and obtained the value of equilibrium pressure within the range of $31.0 \pm 0.2$ up to $31.7 \pm 0.2 \mathrm{~kb}$ which essentially differed from Holland's (1980) data $(29 \cdot 0+0 \cdot 2-30 \cdot 0+0 \cdot 2 \mathrm{~kb})$.

It is obvious that the data obtained at relatively low temperatures $\left(600^{\circ} \mathrm{C}\right)$ using the salt cell are in good agreement with the hydrostatic experimental data. However, at high temperatures $\left(1000^{\circ} \mathrm{C}\right)$, there is a discrepancy in the pressure measurement related to albite breakdown line. The same is true for the $Q=C$ s equilibrium. Salt cells $(\mathrm{NaCl})$ were used three times during the study of this equilibrium. The equilibrium pressures for the last reaction were $29.5 \pm 0.2 \mathrm{~kb}$ (Bohlen and Boettcher 1982), $30.5 \pm 0.2 \mathrm{~kb}$ (Mirwald and Massonne 1980) and $31 \cdot 2 \pm 0.2 \mathrm{~kb}$ (Akella 1979) at $1000^{\circ} \mathrm{C}$. It should be noted that the slopes $(\mathrm{d} P / \mathrm{d} T)$ of equilibrium lines differ markedly from one another, hence the discrepancy in pressure estimation should increase with temperature. The discrepancies have prompted many research workers to study these equilibria accurately.

\section{Starting material and research methods}

The $Q \rightleftarrows C$ s transformation was studied using synthetic $\alpha$-quartz $\left(99 \cdot 99 \% \mathrm{SiO}_{2}\right)$. Coesite was synthesized from quartz. To study the high albite breakdown reaction, quartz, albite and jadeite were mixed in a molar ratio of $1: 1: 1$. High albite and jadeite were synthesized from gel mixture at temperatures decreasing from $1000^{\circ} \mathrm{C}$ to $700^{\circ} \mathrm{C}$ at $6-10^{\circ} \mathrm{C} / \mathrm{s}$ between 18 and $40 \mathrm{~kb}$ respectively. The run products were identified by $\mathrm{X}$-ray diffraction. Reflections $(100,101) ;(002)$ and $(310,311)$ of quartz, albite and jadeite, respectively, were used to determine the direction of the high albite breakdown reaction. The changes of intensities at peaks less than $15 \%$ were taken as 'no reaction'. The starting material was loaded in carefully-sealed platinum capsules, the diameter of which was $3 \mathrm{~mm}$. When the two-capsule technique was applied, they were in the form of hemispheres (refer part 1).

\section{Results}

The experimental results obtained are shown in figure 1 and tables 1 and 2 . The following equations for the equilibrium lines were calculated by the least square method:

$$
\begin{aligned}
& P(\mathrm{~kb})=-1.33+0.0296 T^{\circ} \mathrm{C}(\mathrm{Ab} \rightleftharpoons \mathrm{Jd}+\mathrm{Q}), \\
& P(\mathrm{~kb})=18.949+0.0111 T^{\circ} \mathrm{C}(\mathrm{Q} \rightleftharpoons \mathrm{Cs}), \\
& P(\mathrm{~kb})=16.70+0.013 T^{\circ} \mathrm{C}(\mathrm{Ab} \rightleftharpoons \mathrm{Jd}+\mathrm{Cs}) .
\end{aligned}
$$

In order to calculate the $\mathrm{Ab}=\mathrm{Jd}+\mathrm{Q}$ equilibrium boundary, the data of Hays and Bell (1973) obtained at $600^{\circ} \mathrm{C}$ were taken into account. For pressure calculation, the breakdown of $\mathrm{Ab}$ to $\mathrm{Jd}+\mathrm{Q}$ at $1160^{\circ} \mathrm{C}$ and to the intersection point of the $\mathrm{Ab}=$ $\mathrm{Jd}+\mathrm{Q}$ and $\mathrm{Q}=\mathrm{Cs}$ equilibrium curves were considered. The $P-T$ condition for the intersection point related to these two lines is $31 \cdot 1 \pm 0.5 \mathrm{~kb}$ and $T^{\circ} \mathrm{C}=1096 \pm 10$. The previous data on $Q=C$ s transformation (Ishbulatov 1977) differ markedly from 


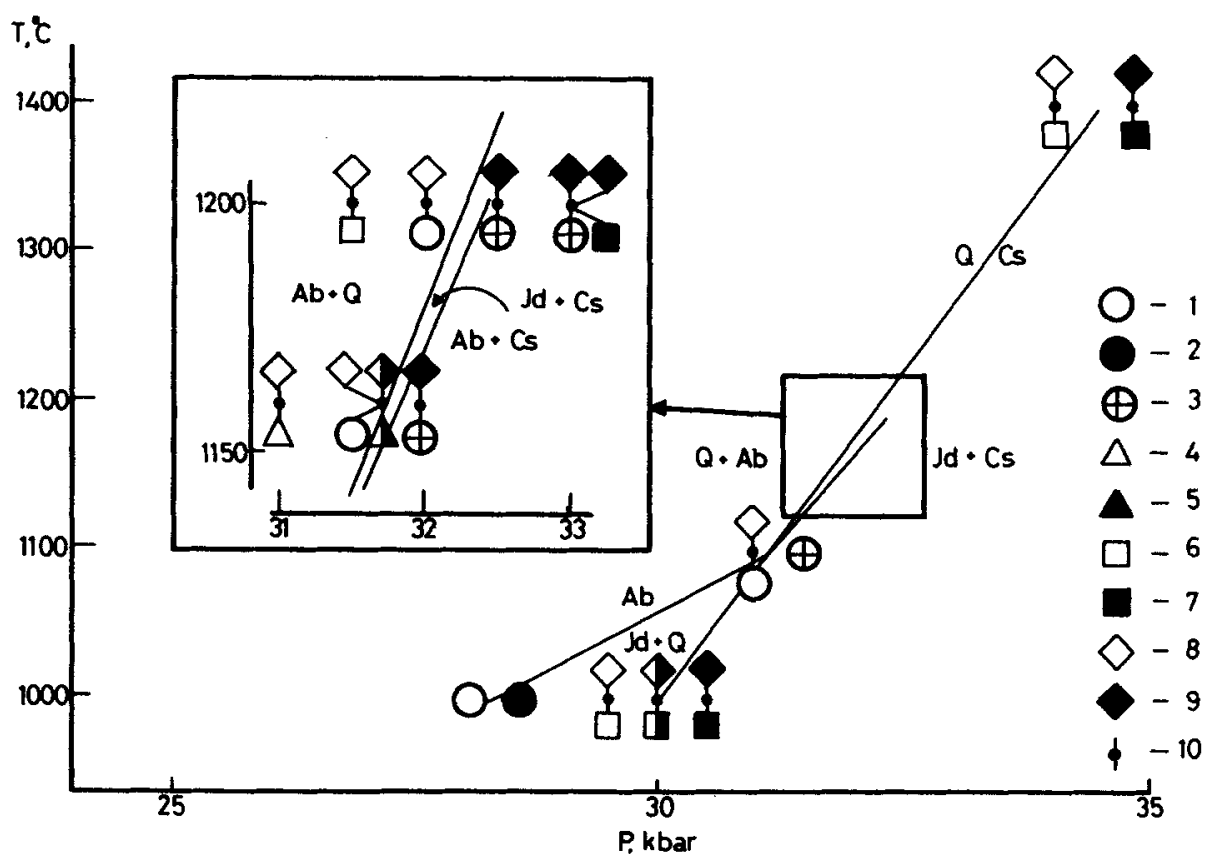

Figure 1. $P-T$ brackets on the $A b \Leftrightarrow J d+Q$ and $Q \Leftrightarrow C$ s equilibria. (Starting material) $\Rightarrow$ [Result]: $1:(\mathrm{Ab}+\mathrm{Jd}+\mathrm{Q}) \Rightarrow[\mathrm{Ab}] ; \quad 2: \quad(\mathrm{Ab}+\mathrm{Jd}+\mathrm{Q}) \Rightarrow[\mathrm{Jd}+\mathrm{Q}] ; \quad 3:(\mathrm{Ab}+\mathrm{Jd}+\mathrm{Q}) \Rightarrow$ $[\mathrm{Jd}+\mathrm{Cs}] ; 4:(\mathrm{Jd}+\mathrm{Cs}) \Rightarrow[\mathrm{Ab}] ; 5:(\mathrm{Jd}+\mathrm{Cs}) \Rightarrow[\mathrm{Jd}+\mathrm{Cs}] ; 6:(\mathrm{Q}) \Rightarrow[\mathrm{Q}] ; 7:(\mathrm{Q}) \Rightarrow[\mathrm{Cs}] ; 8:(\mathrm{Cs}) \Rightarrow$ [Q]; $9:(\mathrm{Cs}) \Rightarrow$ [Cs]; 10: application of the two-capsules method (symbol centre marks the $P-T$ parameters of the run).

Table 1. Comparison of the data on the reaction $A B \rightleftharpoons J d+Q$.

\begin{tabular}{|c|c|c|c|c|}
\hline $\begin{array}{l}P(\mathrm{~kb}) \\
\left(\text { at } 600^{\circ} \mathrm{C}\right)\end{array}$ & $\begin{array}{l}\text { Equation } \\
\text { boundary }\end{array}$ & $\begin{array}{l}\text { Temperature } \\
\text { Range }\left({ }^{\circ} \mathrm{C}\right)\end{array}$ & Apparatus & Reference \\
\hline $16 \cdot 7$ & $P(\mathrm{~kb}) 0.71+0.0290 T^{\circ} \mathrm{C}$ & $600-1105$ & Piston-cylinder & $\begin{array}{l}\text { Mirwald and Massone } \\
(1980)\end{array}$ \\
\hline $17 \cdot 0$ & - & 600 & Calculation & Kelley et al (1953) \\
\hline 18.0 & $6+0.0200$ & $800-1100$ & Hydrostatic & Birch and LeComte (1960) \\
\hline $16 \cdot 7$ & - & 600 & Piston-cylinder & Newton and Smith (1967) \\
\hline 17.8 & - & 600 & Piston-cylinder & Newton and Smith (1967) \\
\hline $16 \cdot 5$ & - & 600 & Calculation & Hlabse and Kleppa (1968) \\
\hline $16 \cdot 3$ & - & 600 & Piston-cylinder & Johannes et al (1971) \\
\hline 16.4 & - & 600 & Hydrostatic & Hays and Bell (1973) \\
\hline $16 \cdot 0$ & - & 600 & Piston-cylinder & Johannes (1978) \\
\hline $16 \cdot 25$ & $0.35+0.0265$ & $600-1200$ & Piston-cylinder & Holland (1980) \\
\hline $16 \cdot 4$ & $-1.33+0.0296$ & $1000-1096$ & Anvil-with-hole & Present study \\
\hline
\end{tabular}

* - extrapolated data 
Table 2. Experimental results on the equilibria $A b J d+Q$ and $Q \mathbf{C s .}$

\begin{tabular}{|c|c|c|c|c|c|}
\hline Run no & $T\left({ }^{\circ} \mathrm{C}\right)$ & $P(\mathrm{~kb})$ & $\begin{array}{c}\text { Time } \\
\text { (hours) }\end{array}$ & $\begin{array}{l}\text { Starting } \\
\text { material }\end{array}$ & Results \\
\hline PC-19 & 1000 & $28 \cdot 1$ & $12 \cdot 5$ & $A b+J d+Q$ & $A b+J d+Q$ \\
\hline PC-35 & 1000 & $28 \cdot 6$ & $24 \cdot 0$ & $A b+J d+Q$ & $\mathbf{J d}+\mathbf{Q} \mathbf{A b}$ \\
\hline$P C^{*}-46$ & 1000 & $29 \cdot 5$ & 1.5 & $\begin{array}{l}\mathrm{Q} \\
\mathrm{Cs}\end{array}$ & $\begin{array}{l}Q \\
Q\end{array}$ \\
\hline$P C^{*}-60$ & 1000 & $30 \cdot 0$ & $1 \cdot 5$ & $\begin{array}{l}\mathrm{Q} \\
\mathrm{Cs}\end{array}$ & $\begin{array}{l}\mathrm{Q}+\mathrm{Cs} \\
\mathrm{Cs}+\mathrm{Q}\end{array}$ \\
\hline $\mathrm{PC}^{*}-49$ & 1000 & $30 \cdot 5$ & $2 \cdot 0$ & $\begin{array}{l}\mathrm{Q} \\
\mathrm{Cs}\end{array}$ & $\begin{array}{l}\text { Cs } \\
\text { Cs }\end{array}$ \\
\hline $\mathrm{PC}^{*}-70$ & 1080 & $30 \cdot 5$ & $4 \cdot 0$ & $\begin{array}{l}Q \\
A b+J d+Q\end{array}$ & $\begin{array}{l}Q \\
A b>J d+Q\end{array}$ \\
\hline$P^{*}-71$ & 1080 & 30.8 & 40 & $\begin{array}{l}Q \\
A b+J d+Q\end{array}$ & $\begin{array}{l}\text { QCs } \\
J d+Q A b\end{array}$ \\
\hline$P C^{*}-72$ & 1080 & $31 \cdot 1$ & $4 \cdot 0$ & $\begin{array}{l}Q \\
A b+J d+Q\end{array}$ & $\begin{array}{l}\mathrm{Cs}>\mathrm{Q} \\
\mathrm{Jd}+\mathrm{QAb}\end{array}$ \\
\hline$P^{*}-52$ & 1100 & $31 \cdot 0$ & $4 \cdot 0$ & $\begin{array}{l}\mathrm{Q} \\
\mathrm{Ab}+\mathrm{Jd}+\mathrm{Q}\end{array}$ & $\begin{array}{l}Q \\
A b>J d+Q\end{array}$ \\
\hline PC-26 & 1100 & $31 \cdot 5$ & $10-0$ & $\mathbf{A b}+\mathbf{J d}+\mathbf{Q}$ & $\mathrm{Jd}+(\mathrm{Q}, \mathrm{Cs})>\mathrm{Ab}$ \\
\hline$P C^{*}-96$ & 1160 & $31 \cdot 0$ & $2 \cdot 0$ & $\begin{array}{l}\mathrm{Q} \\
\mathrm{Jd}+\mathrm{Cs}\end{array}$ & $\begin{array}{l}Q \\
A b>J d+(Q, C s)\end{array}$ \\
\hline$P C^{*}-95$ & 1160 & 31.75 & $2 \cdot 0$ & $\begin{array}{l}\mathrm{Q} \\
\mathrm{Jd}+\mathrm{Cs}\end{array}$ & $\begin{array}{l}\mathrm{Cs}+\mathrm{Q} \\
\mathrm{Jd}+(\mathrm{Cs}+\mathrm{Q}), \mathrm{Ab}\end{array}$ \\
\hline$P C^{*}-53$ & 1160 & $31 \cdot 75$ & $1 \cdot 6$ & $\begin{array}{l}Q \\
A b+J d+Q\end{array}$ & $\begin{array}{l}Q \\
A b+J d+Q\end{array}$ \\
\hline$P C *-51$ & 1160 & 32.0 & $1 \cdot 6$ & $\begin{array}{l}Q \\
A b+J d+Q\end{array}$ & $\begin{array}{l}\mathrm{Cs} \\
\mathrm{Jd}+(\mathrm{Cs}, \mathrm{Q})\end{array}$ \\
\hline$P C^{*}-43$ & 1200 & $31 \cdot 5$ & 1.0 & $\begin{array}{l}\mathrm{Q} \\
\mathrm{Cs}\end{array}$ & $\begin{array}{l}Q \\
Q\end{array}$ \\
\hline$P^{*}-54$ & 1200 & $32 \cdot 0$ & $1 \cdot 2$ & $\begin{array}{l}Q \\
A b+J d+Q\end{array}$ & $\begin{array}{l}Q \\
A b>J d+Q\end{array}$ \\
\hline $\mathrm{PC}^{*}-56$ & 1200 & $32 \cdot 5$ & 1.8 & $\begin{array}{l}\mathrm{Q} \\
\mathbf{A b}+J d+Q\end{array}$ & $\begin{array}{l}\mathrm{Cs} Q \\
\mathrm{Jd}+(\mathrm{Cs}, \mathrm{Q})>\mathrm{Ab}\end{array}$ \\
\hline$P C^{*}-58$ & 1200 & 330 & 1.7 & $\begin{array}{l}Q \\
A b+J d+Q\end{array}$ & $\begin{array}{l}\text { Cs } \\
\mathrm{Jd}+(\mathrm{Cs}, \mathrm{Q})\end{array}$ \\
\hline$P C^{*}-39$ & 1200 & $33 \cdot 0$ & 10 & $\begin{array}{l}\mathrm{Q} \\
\mathrm{Cs}\end{array}$ & $\begin{array}{l}\text { Cs } \\
\text { Cs }\end{array}$ \\
\hline$P C^{*}-61$ & 1400 & $34 \cdot 0$ & 0.5 & $\begin{array}{l}\mathrm{Q} \\
\mathrm{Cs}\end{array}$ & $\begin{array}{l}\mathbf{Q} \\
\mathbf{Q}\end{array}$ \\
\hline$P C^{*}-62$ & 1400 & $34 \cdot 8$ & 0.5 & $\begin{array}{l}\mathrm{Q} \\
\mathrm{Cs}\end{array}$ & $\begin{array}{l}\mathrm{Cs} \\
\mathrm{Cs}\end{array}$ \\
\hline
\end{tabular}

the present data. A possible explanation of this could be that the pressure distribution in the working part of the cell as investigated earlier is not uniform.

\section{Discussion}

The two-capsule technique allowed determination of the temperature of intersection of the two equilibrium curves $Q \rightleftharpoons C$ s and $A b \rightleftharpoons J d+Q$ very accurately with a high 


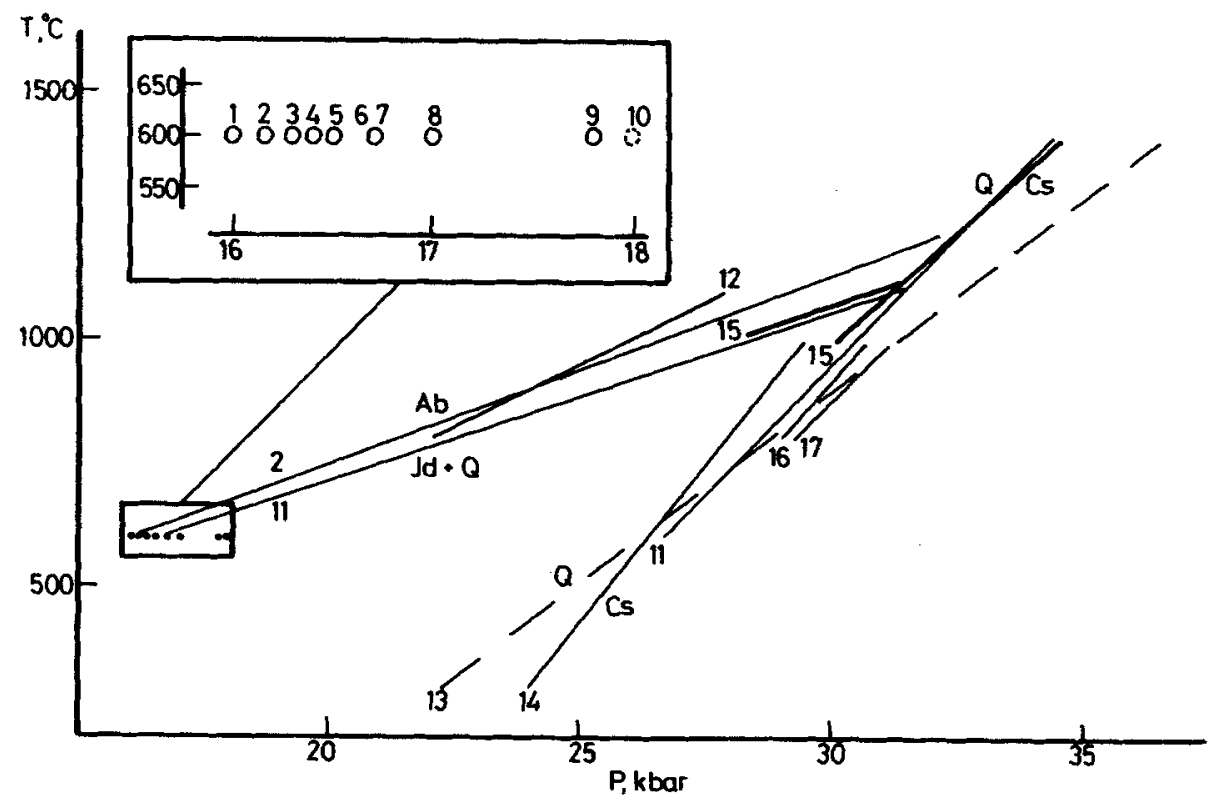

Figure 2. Results of various investigators on the quartz-coesite transition and albite breakdown reaction. References: 1: Johannes (1978); 2: Holland (1980); 3: Johannes et al (1971); 4: Hays and Bell (1973); 5: Hlabse and Kleppa (1968); 6: Newton and Smith (1967); 7: Mirwald and Massone (1980); 8: Kelley et al (1953); 9: Newton et al (1968); 10: Birch and LeComte (1960); 11: Mirwald and Massone (1980); 12: Birch and LeComte (1960); 13: Weaver et al (1979); 14: Bohlen and Boettcher (1982); 15: Present work; 16: Akella (1979); 17: Akella (1978).

degree of precision. In the temperature measurements there was no change in the reading of the thermocouples during the experiments.

The data on the temperature of intersection of the two aforesaid equilibrium curves enable us to comment on $\boldsymbol{P}-\boldsymbol{T}$ pressure calibration by different workers. The intersection point as determined by various independent investigators will be similar only if the true equilibrium parameters have been determined, or else it can be assumed that the same systematic error has been made in the measurement of pressure and temperature.

Let us consider the results of previous investigations presented in figure 2 and tables 1 and 2.

In our experiments the two wires of thermocouples were of $\mathrm{Pt}-\mathrm{Rh}$ alloys of different compositions, whereas in other studies $\mathrm{Pt}_{100}-(\mathrm{Pt}-\mathrm{Rh})$ thermocouples were used.

Unfortunately, at present, there are no generally accepted corrections for the effect of pressure on the e.m.f. According to the available data (Getting and Kennedy 1970) this correction amounts to about $20^{\circ} \mathrm{C}$ (within the $P-T$ range of our investigation) if the $\mathrm{Pt} / \mathrm{Pt}-\mathrm{Rh}$ thermocouple is used. While bracketing the reactions $\pm 20^{\circ}$ has been assumed for our measurements in order to take into account the effect of pressure on the e.m.f. of different thermocouples.

The results compared in table 3 indicate good agreement with the results reported by Mirwald and Massonne (1980). Applying our proposed method, the comparison of $P-T$ calibration data seems (using $A b \rightleftharpoons J d+Q$ and $Q \rightleftharpoons C s$ equilibria curve) impracticable at present, because data on the high albite breakdown reaction within 
Table 3. Comparison of the data on the equilibria $\mathbf{A b} \mathbf{J d}+\mathbf{Q}$.

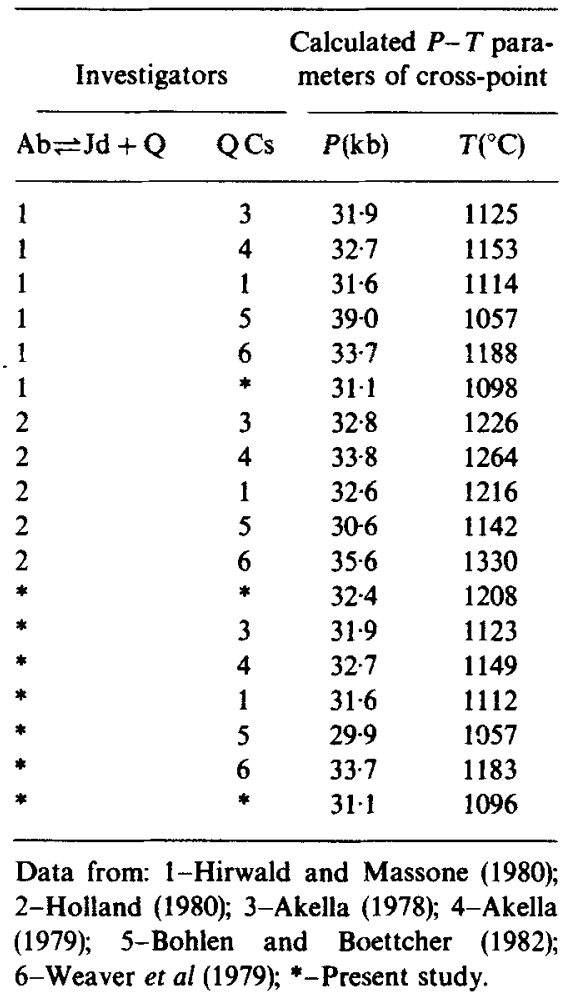

the $P-T$ range of our study are scarce. Except for our data as well as that of Mirwald and Massonne (1980) and Holland (1980) no other data are available for comparison. The data presented in the first two studies essentially differ from the third one. The discrepancy at $1100^{\circ} \mathrm{C}$ exceeds $1.5 \mathrm{~kb}$ due to corrections in pressure measurements and, therefore, deserves special attention.

Before discussing the discrepancy, it should be mentioned that comparison of the data on the high albite breakdown reaction is possible only if the equally-ordered albite was used in all experiments. Otherwise, there would be a considerable discrepancy between the equilibrium boundaries which do not depend only on the pressure measurements. Analyses of the available experimental and thermochemical data on the breakdown reaction (in connection with albite disordering) has been made by Hemingway et al (1981). The analysis confirms that (i) maximum albite disordering can be viewed only at temperatures near the melting point; (ii) there is no albite ordering under dry conditions with decreasing temperature and within the time required to conduct the experiments; (iii) the maximum disordered albite cannot be formed from the Jd $+Q$ mixture. The latter helps to explain the discrepancy between our data and that of Holland (1980), who reported that his runs at and above $1100^{\circ} \mathrm{C}$ cannot be considered reversed, as the albite breakdown to jadeite + quartz during the approach to the final $P-T$ conditions. This implies crystallization of newly nucleated albite with unknown ordering during experiments rather than the totally disordered albite used in the starting material. Albite remained unaffected in our experiments, 
because while approaching equilibrium $P-T$ condition the starting albite remained stable. This may be the possible interpretation for the discrepancy observed in these data.

On the other hand one should consider that our experiments are not reversible. Contrary to the results of Holland (1980), Jd and Q in our starting mixture reacted to produce albite during the approach of the final $P-T$ conditions. It follows from the data of Hays and Bell (1973) that at $600^{\circ} \mathrm{C}$, albite synthesis and its breakdown reaction can take place under different pressures of 16.2 and $16.7 \mathrm{~kb}$, respectively. It is quite probable that the reaction $\mathrm{Ab} \rightleftarrows \mathrm{Jd}+\mathrm{Q}$ is characterized by a certain hysteresis curve which can be considered to be responsible for the discrepancy between the data of Holland and our results. This problem can be resolved comparing piston-in and piston-out run data, but in the anvil-with-hole apparatus, outstroke procedures are practically impossible. In the piston-cylinder apparatus the friction corrections for the piston-in and piston-out runs are inadequate, these add to the uncertainties of pressure estimation.

\section{Acknowledgements}

This paper is dedicated to the late Sir C V Raman, on the occasion of his birth centenary.

\section{References}

Akella J 1978 Reexamination of quartz-coesite transition at 1273 and 1073'K (abstr); Trans. Am. Geophys. Union. 59402

Akella J 1979 Quartz-coesite transition and the comparative friction measurements in piston-cylinder apparatus using talk-alsimag-glass (TAG) and $\mathrm{NaCl}$ cells; Neues Jahrb. Mineral., Monatsh. 5 217-224

Birch F and LeComte P 1960 Temperature-pressure plan for albite composition; Am. J. Sci. 258 209-217

Bohlen S R and Boettcher A L 1982 The quartz-coesite transformation: A precise determination and the effects of other components; J. Geophys. Res. 87 7073-7078

Getting I C and Kennedy G C 1970 Effect of pressure on the e.m.f. of chromel-alumel and platinumplatinum 10\% rhodium thermocouples; J. Appl. Phys. $414552-4562$

Hays J F and Bell P M 1973 Albite-jadeite-quartz equilibrium: A hydrostatic determination; Carnegie Inst. Washington Yearb. 72 706-708

Hemingway B S, Krupka K M and Robie R A 1981 Heat capacities of the alkali feldspars between 350 and $1000 \mathrm{~K}$ from differential scanning calorimetry, the thermodynamic functions of the alkali feldspars from 298.15 to $1400^{\prime} \mathrm{K}$ and the reaction quartz + jadeite = analbite; Am. Mineral. 66 1202-1215

Hlabse T and Kleppa O J 1968 The thermochemistry of jadeite; Am. Mineral. 53 1281-1292

Holland T J B 1980 The reaction albite = jadeite + quartz determined experimentally in the range of 600-1200'C; Am. Mineral. 65 129-134

Ishbulatov R A 1977 Experimental investigation of calc-alkali rocks at 25-40kbar. In Physical-chemical petrology. VI. (Moscow M Nauka) pp. 96-169

Johannes W 1978 Pressure comparing experiments with $\mathrm{NaCl}, \mathrm{AgCl}$, talk, and pyrophyllite assemblies in piston-cylinder apparatus; Neues Jahrb. Mineral., Monatsh. 2 84-88

Johannes W, Bell P M, Mao H K, Boettcher A L, Chipman D W, Hays J F, Newton R S and Seifert F 1971 An interlaboratory comparison of piston-cylinder pressure calibration using the albite breakdown reaction; Contrib. Mineral. Petrol. 32 24-38

Kelley K K, Told S S, Orr P L, King E G and Bonnicksen K R 1953 Thermodynamic properties of sodiumaluminium and potassium-aluminum silicates; U.S., Bur. Mines, Rept. Invest. 495521 
Mirwald P M and Massone H J 1980 The low-high quartz and quartz-coesite transition to 40 kbar between 600 and $1600^{\prime} \mathrm{C}$ and some reconnaissance data on the effect of $\mathrm{NaAlO}_{2}$ component on the low quartzcoesite transition; J. Geophys. Res. 85 6983-6991

Newton M S and Kennedy G C 1968 Jadeite, analcite, nepheline and albite at high temperatures and pressures; Amer. J. Sci. 266 728-735

Newton R C and Smith J V 1967 Investigations concerning the breakdown of albite at depth in the Earth; J. Geol. 75 268-286

Weaver J S, Chipman D W and Takahashi T 1979 Comparison between thermochemical and phase stability data for the quartz-coesite-stishovite transformation; Am. Mineral. 64 604-614 